\title{
How do Lecturers Teach?: Students' Assessment of Lecturers' Attributes in a Selected University in Zimbabwe
}

\author{
Chauraya Efiritha \\ Midlands State University, Zimbabwe \\ Madzanire Daniel \\ Great Zimbabwe University, Zimbabwe \\ Maphosa Cosmas \\ University of Fort Hare, South Africa \\ Zikhali Joyce \\ University of Johannesburg, South Africa
}

\section{Doi:10.5901/mjss.2014.v5n7p307}

\begin{abstract}
Teaching and learning transactions depend on lecturer attributes which in turn influence the way the way lecturers teach. This study sought to establish how university students in one selected Zimbabwean university assessed their lecturers' attributes. The study adopted a descriptive survey approach which utilized both qualitative and quantitative methodologies. Data were solicited from students in five selected faculties in the one selected university. A convenient sample of 110 students participated in the study. A semi-structured questionnaire was used to collect both quantitative and qualitative data. Quantitative data were analysed with the aid of the SPSS statistical software package version 21. Qualitative data were analysed using content analysis method and presented through verbatim quotations of the respondents. The study found that respondents assessed lectured as strong in areas that include preparedness, enthusiasm in teaching and learning, content mastery, approachability, use of different teaching approaches and providing accessible references but weak in taking care of diverse students' backgrounds. It is concluded that while their strengths in lecturer attributes there were also weaknesses. Programmes and measures should be put in place to professional develop lecturers to perfect the strengths and improve on weaknesses.
\end{abstract}

Keywords: teaching and learning; lecturer attributes; lecturers; students; university

\section{Introduction}

Effective university teaching is affected by such factors as reduction in student funding, greater proportion of students and tension in the university niche inter alia. Reduction in student funding makes education expensive for students (Biggs \& Tang, 2007; Scott \& Scott, 2013). It also forces universities to concentrate on attracting students (clients) in large numbers in order to raise funds. Effective teaching suffers as universities strive to raise funds.

Apart from reduction in student funding, effective university teaching is affected by a greater proportion of students in higher education. Biggs and Tang (2007) report that over $40 \%$ of school leavers absorbed in universities have a wide range of abilities in classes that present teaching-related problems to staff. In the words of Biggs and Tang (2007:3), "maintaining standards where the quality of students is so diverse is indeed impossible."

The university niche itself has consequences on effective teaching. The existence of tension between predominant functions in universities namely research, teaching and service (Dewar, 2002; Scott \& Scott, 2013) impacts heavily on effective teaching. Knapper (2010) found that universities are largely ignorant of the knowledge base in teaching and learning although they prepare scholars for their research pursuits through higher degree programmes. Scott \& Scott (2013) observe that there is a misconception enshrined in the university culture that being a competent researcher automatically translates into being an effective lecturer. Effective teaching is much more than research. Staff 
development centres that carry out research on teaching and learning in universities have identified principles of good teaching which include among others: constructive alignment, focus on deep learning, creating a viable teaching learning climate, sound assessment procedures, use of technology, good supervision, emphasizing integration of theory and knowledge with professional practice and research and learning for educators (Ferguson, 2010; David, 2013; Lagueux, 2004).

Constructive alignment requires teaching-learning activities and assessment tasks to be systematically aligned to intended learning outcomes (Biggs \& Tang, 2007). Having aligned learning activities, assessment and teaching; an effective university lecturer emphasizes the deep approach to learning. Scott and Scott (2013) aver that deep learning is linked to students delving into more complex concepts, principles and relationships within the topics and exploring their understanding in more intricate and multifaceted manners. Both constructive alignment and pursuit of deep meaning cannot be realised if a viable teaching and learning climate is not created. A teaching-learning climate refers to the quality of relationship set up between the lecturer and students and the way students feel about it (Biggs \& Tang, 2007). The teaching learning climate comprises an appropriate motivational context where learners learn best when they feel free to move, able to make decisions and are trusted (Lagueux, 2004; David, 2013; Griffith University, 2013). An effective university lecturer carries out research continually. David (2013) affirms that effective teaching depends on the research and learning of the educator who teaches and carries out research to support the learning of others. Good university teaching cannot thrive where technology is sidelined. Lagueux (2004) observes that use of technology particularly the internet facilitates learning particularly the e-learning platform.

Effective university teaching is affected by reduction in students funding, greater proportion of students and tension in the university core functions. However, effective university teaching can be enhanced by constructive alignment, focus on deep meaning, creating teaching climate, research as well as effective use of technology.

\subsection{Active learning strategies}

Research on pedagogy has made a lot of noise in support of active learning at all levels of education especially at university level where the traditional lecture method has dominated the scene for time (University of North Carolina, (UNC) 2009). In the context of university teaching, active learning is where "learners are involved in the learning process when they reflect on what they are doing in the classroom" (Dias, 2011:2). In fact two key components are embedded in active learning. These are 'doing' and 'reflecting' (Millis, 2013:1; Bonwell, 2013:2). Emphasizing the need for learners to reflect what they are doing, Zull (2011) uses the term metacognition and argues that learners should understand their own understanding. In short, active learning entails engaging learners doing activities and thinking about them (Prince, 2004; Amrose, Bridges, DiPietro, Lovett and Norman, 2010; Hestenes, 2012; Eison, 2010).

Literature is fraught with gestures in favour of active learning. It is argued that active learning is vital for the mastery of skills such as critical thinking and problem solving (UNC, 2009). Carnes (2011) notes that problem solving results in strong pedagogical gains. Through active learning, learners can engage in higher order thinking (analysis, synthesis and evaluation) (Bloom, 1956).

Apart from fostering problem solving and thinking skills, active learning contributes to students likelihood of persisting to programme completion (Braxton, Jones, Hirschy and Hartley, 2008; Prince, 2004). Universities that have low completion rate can employ active learning strategies to uplift it (Nelson, 2010). Braxton, Milem and Sullivan (2000) found that active learning may influence students' school integration, commitment to the institution and their decision whether to remain in school.

The fact that active learning strategies accommodate a variety of learning styles elevates them to become teaching-learning strategies of choice. Dias (2011) observes that active learning strategies make students do more than listening: they read, write, discuss and involve themselves in reflective activities. Thus, active learning strategies appeal to individual differences.

Austin and Mescia (2013) observe that active learning strategies empower students to take primary responsibility for their education. Hestenes (2012) suggests that students have to be active in developing their knowledge. In light of this observation, students who take part in their learning can easily bear other responsibilities later in life.

Active learning strategies are valuable for recall of information. Prince (2004) reports that by introducing activities into lectures, students can significantly improve recall of information. Thus skills and concepts acquired through active learning strategies can be easily recalled and applied in examinations and real-life situations.

In implementing active learning strategies lecturers face the hurdle of balancing between covering content and providing student the opportunity to actively engage in with it (Dias, 2011). Bonwell (2013) notes that the risk associated with active learning is that students will not learn sufficient course content. Concomitantly, classroom management is also 
a challenge especially during active learning activities such as discussion and group work where efficient management becomes essential (Dias, 2011).

Strategies that enhance active learning include inter alia, questioning techniques, small groups whole class involvement reading and writing exercises, visual aids, common case studies and field study. The first two will be elaborated in this paper.

Questioning techniques involve students by asking questions during the lecture that require them to apply the introduced concepts and principles (UNC, 2009). The technique permits the lecturer to check if students understand the material. In that vein, Dias (2011) and Eison (2010) advise lecturers to hold breaks at strategic times so that students can complete their notes while discussing the material with a classmate. The breaks should last a few minutes to allow students a chance to talk about the material and think about it. In so doing, learners get engaged.

Small groups are indispensable in active learning in that they get students to really think about the material so that they are able to vocalize their thoughts (UNC, 2009). They can be implemented executed in form of approaches like think-pair-share, buzz groups or three- step interview. With the think-pair- share method, the lecturer simply poses a problem to the class and gives students 30-60 seconds to think about or write a response. Students then pair up and explain their responses for 3- 5 minutes. Finally, the class discusses the results (Eison, 2010; Millis, 2013; UNC, 2009). Mckeachie (2006) suggests that buzz groups enhance participation in a mass lecture. Lecturers ask students to form groups of 5- 8 people to talk about an issue that leads itself to discussion. Each member is asked to contribute at least an idea to the discussion. In doing so, life is added onto a lecture. With a three-step interview, students first work in pairs. The first person in the dyad interviews the second. The second person interviews the first. Next, step two, dyads work together. One person from the first dyad explains their summary to the second dyad. The same is done by the individuals from the second dyad (UNC, 2009). As these small groups are engaged learners get involved.

\subsection{Important lecturer attributes}

Effective university lecturers are typified by among other things by personal attributes they possess. Research about important attributes of lecturers, carried out in many countries is summed up in six key constructs identified by Barnes and Lock (2010) as well as Herfernan, Morrison, Sweeney and Jarratt (2009). These include: rapport, dynamic delivery, knowledge and credibility, communication skills of a lecturer, fairness as well as organisation and preparation.

Rapport is one of the key attributes of a good university lecturer. It refers to an "ability to maintain harmonious relationships based on affinity for others" (Faranda \& Clarke, 2004:274). Researchers have used such words as care, respect, approachability, concern, empathy, fairness and friendliness to describe rapport (Xiao, 2006; Rammal, 2006). Basically, rapport hinges on the relationship between a lecturer and a student. If well enhanced, rapport accrues benefits such as greater learning and higher levels of involvement on the part of the learner (Granitz, Koerning \& Harich, 2009). Chireshe (2011) found that rapport affects class atmosphere and enhances other attributes in turn. Faranda and Clarke (2004) found positive links between rapport and communication which is yet another attribute of an effective university lecturer.

Communication skills of a lecturer are critical in university teaching. Communication in educational circles relates to the lecturer's ability to explain complex concepts clearly and skillfully (Greiniel- Fuhrmann \& Geyer, 2003). To enhance effective communication a lecturer should involve students in interaction, encourage class discussions, clarify course objectives, clearly permit students to share their ideas with peers. Transparent communication was found to enhance teaching and learning (Lang, 2007; Faranda \& Clarke, 2004). To refine communication skills, lecturers should work on their diction and pronunciation. The pitch, volume and tone of their presentations should be varied in order to keep students interested (Campbell \& Davis, 2006). With good communication skills dynamic delivery of content is achieved.

Dynamic delivery is an essential attribute of a lecturer. It is the ability to motivate students through being enthusiastic and entertaining (Heffernan et al, 2009; Barnes \& Lock, 2010). According to Jin (2000) a dynamic lecturer is one who is interesting, charismatic and humorous. Research has revealed that dynamic delivery entails preparing students for examinations giving clear explanations, using good examples, varying delivery methods, using students' native language discreetly (Grieniel- Fuhrmann, 2003; Rammal, 2006; Xiao, 2006). Notably, dynamic delivery interlocks with good rapport and sharp communication skills. Focusing on how lectures are conducted, students in a research conducted by Chireshe (2011), Barnes and Lock (2010) articulated that effective lecturers were those who delivered lectures well, give handouts and use teaching aids.

Effective lecturers should also be knowledgeable and credible. It emerged in on online student survey conducted at Memorial University in Newfoundland that students rarely separated content knowledge and the ability to teach well (Delaney, Johnson, Johnson \& Treslan, 2008). Effective lecturers should be competent in their subject areas (Chireshe, 
2011; Mohidin, Jaidi, Song \& Osman, 2009; Voss and Gruber, 2006). In line with this view, lecturers have to maintain credibility by engaging in current and active, ongoing research in their fields of study.

Fairness cannot be ignored in as far as lecturing is concerned. Literature reveals that fair lecturers treat all students impartially, produce examinations which closely related to the work covered in class, give prompt feedback on assignments and grade impartially (Chireshe, 2011; Barnes \& Lock, 2010). Unfair lecturers (ineffective ones) just give ticks without comments on strengths and weaknesses of the assignment. They are also accused of favoritism. Chireshe and Chireshe (2010) found that teachers' college students accused some lecturers of awarding high marks to their girlfriends. Fairness brings about integrity and credibility of a university lecturer.

An effective university lecturer is expected to be well- organized and prepared. Barnes and Lock (2010) indicate that an organised lecturer prepares each lecture well, sequencing material. On top of that, course objectives are clearly communicated to enhance transparency in lecturing (Lang, 2007). Students' focus is enhanced when a presenter is wellorganised and prepared.

Schleicher (2012:38) points out to the importance of content mastery by teachers as a prerequisite attribute for effective teaching by stating that:

Teachers need to be well-versed in the subjects they teach in order to be adept at using different methods and, if necessary, changing their approaches to optimize learning. This includes content-specific strategies and methods to teach specific content.

It is clear from the above assertion that content expertise really makes a lecturer in the university. It is within the confines of content mastery that the teacher can apply different teaching and learning methodologies.

On the issue of teacher preparedness in teaching, which also applies to university teachers, Wilson, Floden and Ferrini-Mundy (2001) argue that teachers need pedagogical preparation. Such preparation allows them to make use of different methods of facilitating learning and such methods are drawn from learning theories and foundations of education. In the actual facilitation of learning at university level, the university teacher should show clear awareness of different approaches of facilitating learning.

Lecturers in the university should also adequately prepare for their lectures. Preparedness for lectures is a very important positive attribute of a lecturer. The University of Minnesota Centre for Teaching and Learning (2011) explains that lecturing refers to both planning and delivering classroom presentations. This shows that one cannot teach well unless they devote more time and attention to preparation of what will be taught. The University of Minnesota Centre for Teaching and Learning (2011) further shows planning will include how to introduce lectures, giving brief overview of the lecture's content as well as defining and explaining new and unfamiliar terminology that students will encounter in the lecture. Lecturers will also plan how the lecture will be organized and concluded. In this view, nothing happens by chance and all issues regarding teaching and learning are given adequate prior attention.

The issue of diversity in the student body is a reality in universities (May, 2012). In support of this view, Galligan et al (2013) confirm that increased diversity in Australian university in the last fifteen years. Galligan et al (2013: 1) note that lecturers experience challenges in dealing with diversity which takes different forms as they state that:

This diversity covers not just cultural or socio-economic diversity but also academic background, experiences and views.

Given the complex nature of diversity of students found in universities today, it cannot be business as usual and lecturers should be adequately prepared to deal with such diversity. Dealing with diversity among students becomes an important attribute of a lecturer.

It is essential that university lecturers continually reflect upon their personal attributes if they are to become effective in their endeavours. What makes university lecturers competent are the personal attributes they dispose.

\section{Research Methodology}

This section describes and justifies research methodology employed for this study. This is done by addressing research design, population and sampling, data collection instruments, validity and reliability, data analysis and ethical issues.

\subsection{Research Design}

This descriptive survey adopted both qualitative and quantitative methodologies. Johnson and Christensen (2000:312) 
say that qualitative research "relies primarily on the collection of qualitative data (non-numerical data such as words and pictures)". McEwan and McEwan (2003) regard the descriptive aspect as a strength which enables a researcher to take in as much detail as possible. In this study, the qualitative aspect enabled an exploration of students' perceptions of their lecturers' attributes while the quantitative aspect complimented the qualitative data.

\subsection{Population and Sampling}

A sample of 110 students (19\%) was chosen from a population of 582 students of a chosen university in Zimbabwe. To make the sample gender sensitive, sixty five males and 45 females were proportionately selected from five faculties namely Science, Education, Social Sciences, Commerce and Arts. Random sampling in the form of lottery method was adopted in selecting 20 participants from each of the faculties on the rationale that it enabled the researchers to control for selection bias. Bloomberg and Volpe (2012) view this as a key feature of quantitative research which enables generalization to a larger population.

\subsection{Instrumentation}

The sole instrument used to collect the data was the semi structured questionnaire. The questionnaire required the respondents to make their own assessment of lecturers attributes that affect one's learning at the institution. The respondents rated the effect on the particular lecturer attribute on a numerical - verbal rating scale from 'very much' (5) to 'not at all' (1). In all, ten with attributes were provided. These were to do with lecturer's preparedness, content mastery, interest/enthusiasm, sympathy to students, approachability by students, use of different teaching approaches, care of students' diverse backgrounds, provision of accessible references, easiness of note taking during lectures and provision of resource materials. Respondents were also given the opportunity to provide their own subjective comments on any of the 10 attributes and even add and comment own attributes that they felt were left out. This was meant to collect verbatim comments from the respondents.

\subsection{Validity and Reliability}

Issues of reliability and validity are factors which the study was concerned about, since the issues are fundamental cornerstones of any research. Through threats to validity and reliability can never be completely erased, their effects, can, however, be attenuated (Ball, 1990). Cognizant of this fact, made us ensure rigor from our actions during the course of research. The actions we employed to ensure rigor were:

- Use of multiple researches, which in itself ensured internal validity. By involving 4 researchers, the study made substantial slides in overcoming the skepticism that greets lone researchers and lone analysts (Patton, 1999).

- All the four researchers were involved were involved in formulating and structuring of the questionnaire. The researchers consistently edited and refined questions in the questionnaire until we were satisfied that they were clear.

- Questions were not biased as they were all worded to be as simple, specific and unambiguous as possible. There was, therefore, no misunderstanding on the part of the participants of what was being asked. This consistency enhanced reliability as the questions appeared to all respondents in exactly the same way.

- All the researchers were involved in the analysis and reviewing of the research findings. We independently analyzed the same set of data and then compared our findings. This, Patton (1999), calls analyst/investigator triangulation, and as alluded to earlier on, ensured validity. On its own investigator triangulation provided an important check on interpretive bias.

\subsection{Data Analysis}

The study collected both quantitative and qualitative data. Quantitative data were analyzed with the aid of the SPSS statistical software package version 21. Qualitative data were analyzed using content analysis method and presented through verbatim questions of the respondents. Briefly the content analysis followed the following steps:

- Firstly, we got to know our data through reading over the written responses. 
- Secondly, we were all involved in the process of marking the underlying ideas in the written responses. This, we, achieved through making a list of ideas (especially in section c), then grouped similar kinds of information in categories, then, later into themes.

- Finally, we tried to find plausible explanations for the findings (Miles \& Huberman, 1994).

\subsection{Ethical Issues}

In carrying out the study, the researchers were cognisant of ethical issues in research. Consent was sort from the participants. Respondents were provided with a copy of informed consent formerly. Participation was purely voluntary, and the respond could withdraw from the study at any time. The researchers ensured that the participants were told about the study and that they understood the purpose of the study. In a bid to protect the dignity of community and confidentially of the participants, information given in this study is not in any way linked to them. There was no cheating or falsifying of data.

\section{Results}

\subsection{Quantitative results on strengths of lecturer attributes}

Tabulated below are quantitative results of respondents on the strength of different lecturer attributes.

Table 1: Students' perceptions of lecturers' strengths on different attributes $(n=110)$

\begin{tabular}{|c|c|c|c|c|c|c|}
\hline \multirow[t]{2}{*}{ Factor considered/Extent of affecting learning } & \multirow{2}{*}{$\begin{array}{c}\begin{array}{c}\text { Very } \\
\text { strong }\end{array} \\
5\end{array}$} & & & & \multirow{2}{*}{$\begin{array}{c}\begin{array}{c}\text { Not at all } \\
\text { strong }\end{array} \\
1\end{array}$} & \multirow[t]{2}{*}{ Mean } \\
\hline & & 4 & 3 & 2 & & \\
\hline Preparedness for lectures & $\begin{array}{c}51 \\
(46.4 \%)\end{array}$ & $\begin{array}{c}46 \\
(41.8 \%)\end{array}$ & $\begin{array}{c}7 \\
(6.4 \%)\end{array}$ & $\begin{array}{c}3 \\
(2.7 \%)\end{array}$ & $\begin{array}{c}3 \\
(2.7 \%)\end{array}$ & 4.26 \\
\hline Content mastery & $\begin{array}{c}44 \\
(40.0 \%)\end{array}$ & $\begin{array}{c}33 \\
(30.0 \%)\end{array}$ & $\begin{array}{c}27 \\
(24.5 \%)\end{array}$ & $\begin{array}{c}3 \\
(2.7 \%)\end{array}$ & $\begin{array}{c}3 \\
(2.7 \%)\end{array}$ & 4.02 \\
\hline Interest/enthusiasm in teaching & $\begin{array}{c}38 \\
(34.5 \%)\end{array}$ & $\begin{array}{c}43 \\
(39.1 \%)\end{array}$ & $\begin{array}{c}22 \\
(20.0 \%)\end{array}$ & $\begin{array}{c}2 \\
(1.8 \%)\end{array}$ & $\begin{array}{c}5 \\
(4.5 \%)\end{array}$ & 3.97 \\
\hline Being sympathetic to students & $\begin{array}{c}25 \\
(22.7) \\
\end{array}$ & $\begin{array}{c}26 \\
(23.6 \%)\end{array}$ & $\begin{array}{c}49 \\
(44.5 \%) \\
\end{array}$ & $\begin{array}{c}6 \\
(5.5 \%) \\
\end{array}$ & $\begin{array}{c}4 \\
(3.6 \%)\end{array}$ & 3.56 \\
\hline Being approachable by students & $\begin{array}{c}31 \\
(28.2 \%)\end{array}$ & $\begin{array}{c}40 \\
(36.3 \%)\end{array}$ & $\begin{array}{c}26 \\
(23.6 \%)\end{array}$ & $\begin{array}{c}6 \\
(5.5 \%)\end{array}$ & $\begin{array}{c}7 \\
(6.4 \%)\end{array}$ & 3.75 \\
\hline Use different teaching approaches & $\begin{array}{c}26 \\
(23.6 \%)\end{array}$ & $\begin{array}{c}31 \\
(28.2 \%)\end{array}$ & $\begin{array}{c}32 \\
(29.1 \%)\end{array}$ & $\begin{array}{c}18 \\
(16.4 \%)\end{array}$ & $\begin{array}{c}3 \\
(2.7 \%)\end{array}$ & 3.54 \\
\hline Take care of diverse students' backgrounds & $\begin{array}{c}20 \\
(18.2 \%)\end{array}$ & $\begin{array}{c}33 \\
(30.0 \%)\end{array}$ & $\begin{array}{c}37 \\
(33.6 \%)\end{array}$ & $\begin{array}{c}17 \\
(15.5 \%)\end{array}$ & $\begin{array}{c}3 \\
(2.7 \%)\end{array}$ & 3.45 \\
\hline Provide accessible references & $\begin{array}{c}34 \\
(30.9 \%\end{array}$ & $\begin{array}{c}24 \\
(21.8 \%)\end{array}$ & $\begin{array}{c}34 \\
(30.9 \%)\end{array}$ & $\begin{array}{c}13 \\
(11.8 \%)\end{array}$ & $\begin{array}{c}5 \\
(4.5 \%)\end{array}$ & 3.63 \\
\hline Give lectures which make it easy to take notes & $\begin{array}{c}25 \\
(22.7 \%)\end{array}$ & $\begin{array}{c}39 \\
(35.5 \%)\end{array}$ & $\begin{array}{c}33 \\
(30.0 \%)\end{array}$ & $\begin{array}{c}7 \\
(6.4 \%)\end{array}$ & $\begin{array}{c}6 \\
(5.5 \%)\end{array}$ & 3.64 \\
\hline $\begin{array}{l}\text { Organize resource materials so that students can learn } \\
\text { for themselves }\end{array}$ & $\begin{array}{c}26 \\
(23.6 \%)\end{array}$ & $\begin{array}{c}31 \\
(28.2 \%)\end{array}$ & $\begin{array}{c}43 \\
(39.1 \%)\end{array}$ & $\begin{array}{c}6 \\
(5.5 \%)\end{array}$ & $\begin{array}{c}4 \\
(3.6 \%)\end{array}$ & 3.63 \\
\hline
\end{tabular}

All the lecturer attributes with a mean response of more than 3.5 were deemed to be strong attributes whereas those with a mean of less than 3.5 were deemed to be weak. The established strong attributes included preparedness, enthusiasm in teaching and learning, content mastery, approachability, use of different teaching approaches and providing accessible references. The only weak attribute was of taking care of diverse students' backgrounds. 


\subsection{Students qualitative responses of factors affecting studies}

\subsubsection{Verbatim quotations on strengths of attributes}

In line with their perceived strengths of lecturer attributes, the respondents made some of the comments listed below:

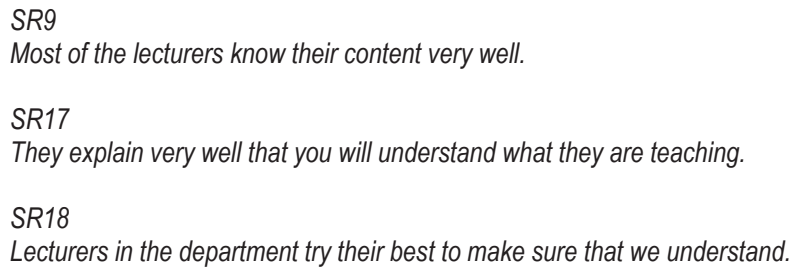

The above verbatim quotations serve to show in respondents' own words what they said regarding strengths of lecturers' attributes.

\subsubsection{Verbatim quotations on weaknesses of attributes}

On the weaknesses perceived in lecturer attributes, respondents made the following comments as shown below:

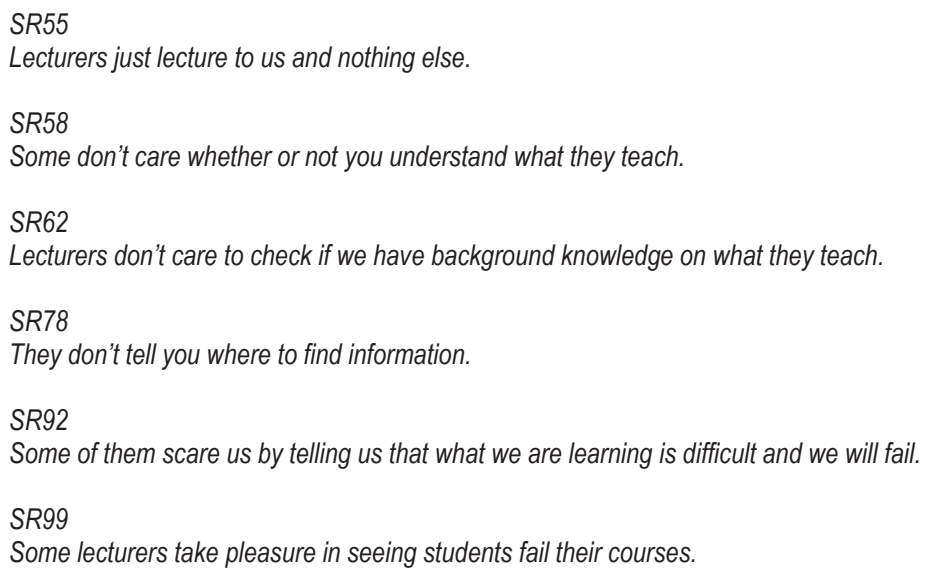

The above quotations show respondents views on the perceived weak attributes of lecturers.

\section{Discussion}

The study established that lecturers had strengths in preparedness for lecturers. Preparedness is an important attribute of a lecture as meaningful teaching and learning thrives of effective preparation. This finding is consistent with views of The University of Minnesota Centre for Teaching and Learning (2011) that planning is very important for lecturers as the quality of delivery during lectures is dependent on investment made in preparation in terms of time and effort. Barnes and Lock (2010) indicate that an organised lecturer prepares each lecture well and sequences material taught to students. In line with calls to professionalize teaching in universities, the issue of planning for one's work becomes a hallmark of a true professional. 
It also emerged from the study that in terms of the respondents' assessment, lecturers had strength in content mastery. This finding corroborates Schleicher's (2012) view that teachers in general should be well-versed in what they teach. Without content mastery, the teaching endeavor becomes futile. In having a teacher who lacks content mastery is tantamount to engaging a blind man to lead other blind men. Schleicher (2012) further observes that with content mastery, the teacher is content-specific teaching approaches as demanded by the nature of content taught.

The study also established lecturers' strength in being approachable by students. It is a very important attribute for the gap between the lecturer and students should be reduced so that the lecturer becomes a co-learner and students can easily approach him or her for assistance. Such a finding confirms earlier findings by Flint and Johnson (2010) that students work well with approachable lecturers compared to working with unapproachable lecturers. Layne (2012) also found that effective teachers are described as approachable. It is also important to note that lecturers themselves require to be aware of the importance of being approachable to students.

The study also established that lecturers were strong in the use of different teaching approaches. This is in line with the observation by Wilson, Floden and Ferrini-Mundy (2001) that teachers need pedagogical preparation. Teaching is an art and Fernández (2013) also calls for the importance of pedagogical knowledge for university. Comments by some of the respondents that some lecturers never cared whether students understood content taught or even enjoyed students' failure stand in contrast to the need for lecturers with pedagogical expertise. Such expertise ensures meaningful facilitation of teaching and learning processes.

It emerged from the study that lecturers had weaknesses in dealing with student diversity. This finding confirms claims by Galligan et al (2013: 1) that lecturers experience challenges in dealing with diversity which takes different forms ranging from social, cultural, ethnic, religious and academic ability differences. Such is a complex phenomenon and lectures would need adequate preparation to understand student diversity and deal with it. Lecturers may need to vary teaching approaches ion order to accommodate different learners in the lecture rooms

\section{Conclusions}

There are different attributes that lecturers exhibit in universities. Some are strong and positive attributes which are important for the enhancement of teaching and learning. There are also negative attributes that are detrimental to meaningful facilitation of learning in classrooms and, invariably, negatively affect student attainment. Students are also in a position to assess their lecturers showing their areas of weakness and strength.

\section{Recommendations}

Against the findings of the study, the following recommendations are made:

- Student evaluation of teaching exercises should be taken seriously in universities. Such exercises, where students evaluate lectures at the end of the course, are important in providing useful feedback to lectures. This allows a lecturer to make an introspection of self, address areas of inadequacy and buttress areas of strength.

- Peer evaluation exercises should also form integral quality assurance measures in universities. Peers should assist each other by observing lectures and commenting on areas of strengths and weaknesses.

- Professional development courses in teaching are very important in assisting lecturers without teaching backgrounds and qualifications to gain skills and expertise in teaching.

- Lecturers should be encouraged and supported to study for qualifications in higher education teaching as such efforts assist in the realization of the goal to professionalize teaching in universities.

- Excellence in teaching awards should be given to excelling lecturers in the university to motivate lecturers who excel in teaching.

- Measures should be put in place in universities to recognize the importance of teaching as a core function of the university in the same way research is accorded high status.

\section{References}

Ambrose, S. A., Bridges, M.W., DiPietro, M., Lovett, M.C., Norman, M. K. (2010). How Learning Works: 7 Research- Based principles for Smart Thinking. San Francisco: Jersey- Bass.

Austin, D., Mescia, N. D. (2013). Strategies to Incorporate Active Learning into Online Teaching. Florida: Centre for Leadership in Public Health Practice COPH, University of South Florida.

Ball, S. J. (1990). Politics and Policy Making in Education. London: Routledge. 
Barnes, B. D., Locke, G. (2010). The Attributes of Effective Lecturers of English as a Foreign Language as Perceived by Students in a Korean University. Australian Journal of Teacher Education, 35 (1): 239- 152.

Biggs, J., Tang, C. (2007). Teaching for Quality Learning at University. London : McGraw Hill.

Bloom, B. S. (1956). Taxonomy of Education Objectives- The Classification of Educational Goals: Handbook I. Cognitive Domain., New York: David Mckay.

Bloomberg, L. D., Volpe, M. (2012). Completing your qualitative dissertation: a road map from beginning to end. Los Angeles: SAGE.

Bonwell, C. C. (2013). Active: Creating Excitement in the Classroom. From www.active-learning-site.com Accessed 20 December 2013.

Braxton, J.M., Jones, W.A., Hischy, A.S., Hartley, H.V. (2008). The Role of Active Learning in College Persistence. New Directions for Teaching and Learning, 115(1): 71-83. From www.intersciencewiley.com Accessed 21 December 2013).

Braxton, J.M., Milem, J. F., Sullivan, A.S. (2000). The Influence of Active learning on the College Student Departure Process: Toward a revision of Tintos Theory. The Journal of Higher Education, 71(5): 669-590.

Campbell, K.S., Davis, L. (2006). The Sociolinguistic Basis of Managing Rapport when Overcoming Buying Objections. Journal of Business Communications 43(1): 43-66.

Carnes, M.C. (2011). Settings Students' Minds on Fire. Chronicle of Higher Education, 52(27):A72

Chireshe, R., Chireshe, E. (2010). Student teachers' perceptions towards teaching practice assessment. South African Journal of Higher Education, 24(4):511-524.

Chireshe, R. (2011). Effective and Ineffective Lecturers: University Students' Perspective in Zimbabwe. Anthropologist, 13(4): 265-269.

David, M. (2013). Effective Learning and Teaching in UK Higher Education: A Commentary by the Teaching and Learning Research Programme. From http://www.tlrp.org/pub/commentaries.htm Accessed 18 December 2013.

Delaney, J., Johnson, A., Johnson, T., Treslan, D. (2008). Students Perceptions of reflective Teaching in Higher Education. Newfoundland: Memorial University.

Dewar, K. (2002). On Being a Good Teacher. Journal of Hospitality Leisure, Sport and Tourism Education, 1(1): 61-67.

Dias, M. (2011). Teaching Lounge: Strategies to Teach for Active Learning. Ottawa: Centre for University Teaching. From www.t/ss.uottawa.ca/cut Accessed 20 December 2013.

Eison, J.E. (2010). Using Active Learning Instructional Strategies to Create Excitement and Enhance learning. Unpublished Manuscript.

Faranda, W.T., Clarke, I. (2004). Student Observations of Outstanding Teaching: Implications for Marketing Educators. Journal of Marketing Education, 23(2): 271-281.

Fernández, T.J. (2013). Professionalisation of teaching in universities: Implications from a training perspective Universities and Knowledge Society Journal, 10(1): 345-358.

Ferguson, R.F. (2010). Student Perceptions of teaching Effectiveness. Discussion brief. Massachusetts: National Centre for Teacher Effectiveness and the Achievement gap Initiative, Havard University.

Galligan, L., Wandel, A., Pigozzo, R., Frederiks, A., Robinson, C., Abdulla, S., Dalby, T. (2013). Students' mathematical preparation Part A: Lecturers' perceptions. Paper presented at the $9^{\text {th }}$ Delta Conference on Teaching and learning of undergraduate mathematics and statistics, $24-29$ November, Kiama, Australia

Granitz, N.A., Koerning, S.K., Harich, K.R. (2009). Now its Personal: Antecedents and Outcomes of Rapport Between Business Faculty and their Students. Journal of Marketing Education, 31(1): 52-65.

Greimel-Fuhrmann, B., Geyer, A. (2003). Students' Evaluation of Teachers and Instructional Quality- Analysis of Relevant Factors Based on Empirical Evaluation research. Assessment and Evaluation in Higher Education, 28(3): 229-238.

Griffith University (2013). Principles to Promote Excellence in Learning and teaching Practices at Griffith University. London: Griffith University.

Horfernan, T., Morrison, M., Sweeney, A., Jarratt, D. (2009). Personal Attributes of Effective Lecturers: The Importance of Dynamism, Communication, Rapport and Applied Knowledge. International Journal of Management, 8(3): 1-25.

Hestenes, D. (2012). In E. Hanford (ed): Physics Seek to Loose the Lecture as a Learning Tool: NPR Broadcast of American Radio Works. From http://www.npr.org/2012/01/01/144550920 Accessed 13 December 2013).

Jin, Z. (2000). The learning Experience of Students in Middlesex University Business School (MUBS): Why do they Enjoy some Modules/ Lectures and Dislike others? International Journal of Management Education, 1(1): 22-36.

Johnson, B \& Christensen, L. (2012).Educational Research: Quantitative, Qualitative, and Mixed Approaches. $4^{\text {th }}$ edition. Washington DC: SAGE Publications.

Knapper, C. (2010). Changing Teaching Practice. Barriers and Strategies. In J.C. Hughes, J. Mighty (eds): Taking Stock: Research on Teaching and Learning in Higher Education. Kingston, ON: School of Policy Studies, Queens University, pp. 229-242.

Lang, M. (2007). Classroom Transparency. The Chronicle of Higher Education. From http://chronicle.com/article/classroomtransparency/46461 Accessed 12 December 2013.

Langueux, R. (2004). Becoming Teachers. New Haven: The McDougal Graduate Teaching Centre. From www.yale.edu/mcdougal/teaching Accessed 10 December 2013.

Layne, L. (2012). Defining effective teaching. Journal on Excellence in College Teaching, 23 (1): 43 - 68

May, M.S. (2012). Diversity dynamics operating between students, lecturers and management in a historically Black university: the lecturers' perspective. South African Journal of Industrial Psychology 38 (2): 1003 - 1111

McEwan, E.K., McEwan, P.J. (2003). Making Sense of Research. Thousand Oaks, CA: Corwin

Mckeachie, W. J., Svinicki, M. (2006). Mckeachie's Teaching Tips: Strategies, research and theory for College and University Teachers. Boston, M.A: Houghton Mifflin. 
Miles, M. B., Huberman, A. M. (1994). Qualitative Data Analysis. Thousand Oaks, CA

Millis, B. J. (2013). Idea paper 53: Active Learning Strategies in Face-to-Face Courses. Manhattan: The idea Centre. From www.theideacentre.org Accessed 15 December 2013.

Mohidini, R., Jaidi, J., Song, L. T., Osman, Z. (2009). Effective Teaching Methods and lecturer Characteristics: A Study on Accounting Students at Universities Malaysia Sabah (UMS). European Journal of Social Sciences, 8(1): 21-29.

Nelson, L.D. (2010). Teaching at its Best: A Research- Based Resource for College Instructors. San Francisco, CA.: Jossey- Bass.

Patton, M. Q. (1990). Enhancing the Quality and Credibility of Qualitative Analysis. www.ncbi.n/m.gov/pmc/articles /PMC1089059/pdf/hresearch00022-0112.pdf. Accessed 12 December 2014.

Prince, M. (2004). Does Active Learning Work? A Review of the Research. Journal of Engineering Education, 93(3): 223- 231. From www.ncsu.edu.felder.public/papers/princeal.pdf Accessed 10 December 2013.

Rammal, S. M. (2006). The Other Side of the Mirror: ESI Students Offer their Opinions of Good Language Teaching. From http://www.usingenglish.com/article/other-side-mirror.html Accessed 19 December 2013.

Schleicher, A. (2012). Preparing teachers and developing school leaders for the $21^{\text {st }}$ century: Lessons from around the World. OECD Publishing. http://dx.doi.org/10.1787/978264. Accessed 20 December 2013

Scott, D.E., Scott, S. (2013). Effective University Teaching and Learning. From www.ucalgary.ca/scott\&scott-EffectiveUniversityTeaching Accessed 20 December 2013.

University of Minnesota Centre for Teaching and Learning (2011). Effective Lecture Preparation and Delivery. From http://www1.umn.edu/ohr/teachlearn/resouces/effective/ Accessed 10 January 2014.

University of North Carolina (UNC)(2009). Classroom Activities for Active Learning. From http://cfe.unc.edu Accessed 24 December 2013.

Voss, R., Gruber, T. (2006). The Desired Teaching Qualities of Lecturers in Higher Education. Quality Assurance in Education, 14(3): 217-242.

Wilson, S.M., Floden, R.E., Ferrini-Mundy, J. (2001). Teacher Preparation Research: Current Knowledge, Gaps and Recommendations. Washington: University of Washington Centre for the Study of Teaching and Policy

Xiao, L. (2006). Bridging the Gap Between Teaching Styles and Learning Styles: A Cross Cultural Perspective. Teaching English as a Second or Foreign Language, 10(3):1-15. From www.tesl-ej.org/ej39/a2.html Accessed 24 December 2013.

Zull, J.E. (2011). From Brain to Mind: Using Neuroscience to Guide Change in Education. Sterling, VA: Stylus Publishing. 